\title{
A figura do avô judeu nas "narrativas de formação" de Ilse Losa e Samuel Rawet
}

The Image of the Jewish Grandfather in the "Formation's Narratives" by Ilse Losa and Samuel Rawet

Karina Marques*

Resumo: A figura do avô judeu ocupa um lugar central em duas narrativas de teor autobiográfico: O mundo em que vivi (1949) de Ilse Losa e "Gringuinho", de Contos do imigrante (1956), de Samuel Rawet. Nelas, o papel do avô é importantíssimo para a consolidação da identidade judaica na infância dos protagonistas, por meio da transmissão de um judaísmo ético e afetivo. No contexto histórico da Segunda Guerra Mundial, marcado pelo antissemitismo na terra natal e pela xenofobia na terra de acolhida, essa figura consolida-se como um esteio comunitário fundamental face à ameaça de desintegração do núcleo familiar judaico. Propomos, portanto, por meio da análise literária das duas narrativas, uma reflexão sócio-histórica em torno dessa figura, que pode ser associada ao ancião bíblico. Pretendemos, ainda, alargar as definições do romance de formação enquanto gênero literário, tomando por base o conto de Rawet.

Palavras-chave: Ilse Losa. Samuel Rawet. Infância.

Abstract: The figure of the jewish grandfather occupies a central position in the two autobiographic narratives: O mundo em que vivi (1949) by Ilse Losa and "Gringuinho", by Samuel Rawet's collection Contos do Imigrante (1956). In these narratives, the role of the grandfather is extremely important for the consolidation of the Jewish identity in the childhood of the characters, transmitting an ethical and affective Judaism. In the historical context surrounding the II World War, marked by anti-Semitism in the native land and xenophobia in the foreign country, such figure of the Jewish grandfather assumes a fundamental communitarian support regarding the threat of disintegration of the Jewish familial core. We thus propose by means of literary analysis of the two narratives, a social-historical reflection on such figure, which can be linked to the biblical elder. We pretend as well, to widen the definitions of novel of formation while literary genre, taking as a starting point the Rawet's short story.

Keywords: Ilse Losa. Samuel Rawet. Childhood. 


\section{Arquivo Maaravi}

A figura do avô remete o leitor à imagem bíblica do "ancião" e desempenha um papel fulcral como esteio ético da criança judia no romance $O$ mundo em que vivi (1949) de Ilse Losa (1913-2006) e no conto "Gringuinho", da coletânea Contos do imigrante (1956), de Samuel Rawet (1929-1984). Esses dois textos abordam a temática do violento amadurecimento humano face à intolerância étnica, num contexto de guerra e de imigração, sendo a figura do "avô" o único elo possível com uma herança judaica em ruínas.

Esses relatos ficcionais oferecem-nos uma reflexão sócio-histórica extremamente interessante sobre o processo de dissolução do núcleo familiar judaico face à opressão dos grupos hegemônicos, assim como sobre o acirramento do antissemitismo na Alemanha com a ascensão de Hitler ao poder e a xenofobia existente no Brasil da era varguista. Ainda, de um ponto de vista literário, eles nos permitem repensar as definições e alargar os limites do "romance de formação" enquanto gênero textual.

Por se tratarem de textos de teor autobiográfico, torna-se essencial a compreensão da história de vida dos dois autores de origem judaica, dentro do panorama histórico do pré-guerra. Paul Ricœur afirma que uma das funções da ficção é "de liberar retrospectivamente certas possibilidades do passado histórico"(RICEUR, 1985, p. 346). ${ }^{1}$ Para Jean-François Chiantaretto, entretanto, a escrita pessoal só pode narrar a história com a condição de que uma situação de interlocução seja criada, "dando lugar ao outro" (CHIANTARETTO, 2002, p. 14), ${ }^{2}$ implicando "ao mesmo tempo múltiplas pertenças e o solo comum da pertença humana" (CHIANTARETTO, 2002, contracapa). ${ }^{3}$ Segundo o autor, depois das catástrofes humanas que marcaram o século 20, o conceito de escrita pessoal deve ser repensada, orientando-se em direção a uma poética menos intimista e mais aberta à alteridade, à experiência de si em relação ao outro.

Podemos constatar assim, que, por intermédio do percurso de amadurecimento de Rose Frankfurter e de Gringuinho, alter egos de Ilse Losa e de Samuel Rawet, uma situação de interlocução é estabelecida com o leitor em torno da memória da Shoah e da diáspora judaica. Uma memória coletiva que, com maior ou menor grau de envolvimento, concerne toda a humanidade em torno desse episódio traumático. Assim, por meio do exercício literário, memória individual e memória coletiva entram em ressonância, rompendo silêncios e preenchendo lacunas do discurso histórico oficial.

Conhecendo alguns fatos da vida de Ilse Losa, não podemos negar as suas semelhanças com o percurso do personagem Rose Frankfurter de O mundo em que vivi. Da infância de Rose até a sua idade adulta, o romance é dividido em quatro partes que correspondem a fatos marcantes na vida da escritora: a infância com 


\section{Arquivo Maaravi}

os avós, a volta para a casa dos pais, a adolescência marcada pela morte do pai e a ida para Berlim onde é interrogada pela Gestapo.

Alemã de origem judaica oriunda do vilarejo de Buer, Ilse Lieblich foge para Portugal, após ter sido interpelada pelos nazistas. A razão do interrogatório é uma carta enviada a uma amiga, criticando severamente a política de Hitler. Portugal foi o destino mais evidente, por lá já estar um irmão também vítima da violência antissemita. Era o ano de 1934 e Losa tinha então 21 anos quando desembarca no Porto desconhecendo por completo a língua portuguesa. Rapidamente, insere-se num grupo de intelectuais anti-salazaristas, numa tentativa, talvez, de travar em sua terra de exílio a luta contra o fascismo que não pôde realizar em sua terra natal. Foi nesse grupo que Losa conheceu o seu marido, o célebre arquiteto Armênio Losa, por meio do qual adquiriu a nacionalidade portuguesa. Torna-se, então, Ilse Losa, nome de pluma com o qual construiu uma carreira literária longa e vasta, escrevendo sempre em sua língua de adoção. Um caso de conversão linguística belo e raro no universo literário lusófono, ainda que doloroso. A esse respeito, ela afirma que "escrever em uma língua estrangeira não se faz nunca por vontade, mas por necessidade. Além do fato de ser um exercício extremamente doloroso, eu nunca atingi a perfeição formal que eu queria" (PALLA, 1973, p. 16-18).

Essa dor provocada pela perda da língua materna é também expressa pelo personagem Gringuinho de Samuel Rawet. Assim como o protagonista do seu conto epônimo, o autor foi uma criança recém-chegada ao Brasil e para o qual, apesar do aprendizado precoce da língua portuguesa, esta nunca foi sentida como familiar: "Não domino bem a língua ainda. E dominá-la não é ser fiel a preceitos gramaticais. É manifestar espontaneamente suas raízes populares" (BRASIL, 1974, p. 3). Aos 7 anos, em 1936, Samuel Rawet deixa o pequeno vilarejo de Klimontów, na Polônia, juntamente com a sua mãe e irmãos. Dirigem-se ao Rio de Janeiro, cidade onde já morava o pai, imigrado em 1933. Segundo Natalia Klidzio, embora o clima de antissemitismo já tivesse atingido a Polônia, a situação entre judeus e poloneses cristãos em Klimontów era, no geral, harmoniosa até o início da guerra, mas a pobreza e a falta de perspectiva inspiraram a imigração. (KLIDZIO, 2007, p. 20).

Tanto o romance $O$ mundo em que vivi quanto o conto "Gringuinho" abordam o tema da dissolução do núcleo familiar e comunitário, associados à perda da terra natal. Por associação metonímica, também, à perda da língua materna primeiramente, o hebraico, depois o alemão e o polonês. O fenômeno de desintegração atinge, portanto, várias esferas da vida dos personagens, da família à nação, provocando uma profunda crise de identidade. Nos dois textos, a indiferença da figura materna reforça esse sentimento de perda, tornando-se o avô a figura de maior carga afetiva. A deterioração dos laços de afetividade 


\section{Arquivo Maaravi}

maternos, a violência da qual a criança é vítima na escola, são um prenúncio de uma ruptura ainda maior: a exclusão tanto no país natal - caso do romance de Losa, - quanto no país de acolhida - como vemos em Rawet. $O$ mundo em que vivi e "Gringuinho", que aqui chamamos de "narrativas de formação", retratam, portanto, o processo de amadurecimento dos personagens pela incorporação do sentimento de exclusão como marca de identidade. No entanto, enquanto, na obra de Losa, Rose Frankfurter rejeita a violência afirmando a beleza da sua alteridade judaica, no conto de Rawet, Gringuinho incorpora a violência do grupo hegemônico e prefere o afastamento.

O mundo em que vivi acompanha o crescimento de Rose Frankfurter, criança judia nascida nas vésperas da Primeira Grande Guerra, vivenciando o recrudescimento do antissemitismo na Alemanha até a ascensão de Hitler ao poder. O romance termina com o interrogatório de Rose pela Gestapo e sua partida para o exílio. Além da violência perpetrada pelo sistema no poder, a protagonista passa por várias situações dolorosas no âmbito familiar e comunitário que ajudam a forjar a sua personalidade: a separação com os avós que a criaram, a indiferença da mãe, os comentários antissemitas de colegas na escola, a violência antissemita contra o pai, a sua morte, a precariedade da mãe viúva dona de uma pensão boicotada pelos alemães e a relação amorosa com Paul, rompida por conta da intolerância social. Em todas as esferas da vida, Rose sofre provações de dor, ainda que enxergue o mundo com um otimismo similar àquele encontrado nos textos de Anne Frank.

Na crônica "Sobre os contos de Anne Frank, Losa exprime sua admiração por esse jovem talento do qual ela foi a primeira tradutora em Portugal: "Anne escrevia por necessidade e não a interessava ufanar-se com as suas produções [...] E o que me parece mais extraordinário é o facto de ela nunca exprimir nem ódio, nem inveja, nem mostrar espírito de vingança" (LOSA, 1997, p. 34). Como vimos, essa necessidade da escrita parece guiar, de forma semelhante, a obra ficcional da escritora portuguesa, pois nela encontramos um desejo de partilhar com o leitor as suas experiências e uma poderosa mensagem de confiança no ser humano.

Num espírito de resistência, observamos que a opressão sofrida contra Rose é proporcional à sua vontade de afirmação da identidade judaica. Com a exclusão, ela apega-se gradualmente ao que lhe tiram: o universo do judaísmo, associado a uma infância feliz em companhia do avô. É a figura sublime desse homem perdido, resplandecendo no início e no fim do romance, que explica a fascinação por esse universo também perdido. Tanto mais preciosos quanto precários são:

O meu avô, homem alto e magro, de cara larga, ossuda e um tanto avermelhada, olhos claros e quase sempre tristes, 


\section{Arquivo Maaravi}

Revista Digital de Estudos Judaicos da UFMG

ISSN: $1982-3053$

tinha o costume de levantar as sobrancelhas espessas quando dizia alguma coisa importante. Isso fascinava-me... (LOSA, 1987, p. 7)

O corpo gela-se-me. Quero viver. Tenho o direito de viver. [...] Quero ir com o avô Markus buscar a Boneca-MaisLinda-do-Mundo. (...) Mas ninguém sabe que minha vida esteve em jogo poucos minutos antes, que eu, judia Frankfurter, tenho cinco dias para deixar o país. (LOSA, 1987, p. 194 e 197)

O avô é a figura que se ergue logo nas primeiras linhas do romance, antes mesmo da apresentação da protagonista. Nele não há cisão entre corpo e alma, tudo inspira Rose ao divino. Sua autoridade faz-se de forma natural, contrariamente às imposições da avó. Compreendemos logo, portanto, a importância desse personagem na vida de Rose, numa relação de adoração por esse modelo ético e afetivo que lhe transmite a força vital necessária para enfrentar o medo diante da polícia nazista. A Boneca-Mais-Linda-do-Mundo nada mais é do que o símbolo da beleza e da esperança alimentada por esse homem. É o nome da boneca que desejava oferecer à neta, contrariando a opinião da avó, que a considerava demasiado cara. Rose nunca teve a boneca, mas o sonho de consegui-la nunca se extinguiu.

Segundo Ana Isabel Marques, "O avô Markus, um homem generoso, com uma postura e um discurso cativantes, é quem personifica a nobreza e a beleza da cultura judaica" (MARQUES, 2001, p. 73). Podemos, portanto, associá-lo à figura do ancião: "na sociedade bíblica, pessoas que adquiriam um estatuto especial de autoridade, em razão da sua idade, da sua sabedoria" (WIGODER, 1996, p. 65). ${ }^{4}$ Ainda que a sabedoria do avô Markus não venha de uma erudição, ele possui uma sabedoria prática, ligada ao saber viver com o outro e ao saber vivenciar e transmitir os ensinamentos judaicos. Ele é apresentado no romance como os anciãos "encarregados de fazer a experiência da divina Presença, de receber a inspiração e partilhar a responsabilidade do mandamento com Moisés" (WIGODER, 1996, p. 65). ${ }^{5}$

No trecho seguinte, podemos ver explicitamente o avô assumindo o papel de transmissor dos ensinamentos judaicos à Rose, fazendo-a compreender $\mathrm{o}$ judaísmo sob um viés menos dogmático e mais afetivo:

O cantor tirava um rolo e entregava-o a um dos homens, que lhe pegava com a cautela e o carinho como se pega em meninos de colo. $\mathrm{O}$ avô explicava-me: continha os cinco livros de Moisés, a mais grandiosa figura das histórias da Bíblia que libertara o povo de Israel da escravidão [...]. Ao 
falar das cerimónias da sinagoga, o avô gostava de empregar palavras invulgares e pesadas, que me soavam como música ou que via bailar no espaço como as letras hebraicas. (LOSA, 1987, p. 41)

A imagem dos "meninos de colo" associada aos rolos da Torá nos remete à sensação de acolhimento que a menina Rose encontra no seio da comunidade judaica. Segundo Marques, a protagonista tem "uma percepção fortemente sensorial, onde predominam os aspectos acústicos e cromáticos, traduz, no fundo, a forma espontânea e imediatista como a criança capta esses movimentos iniciáticos" (p. 73). É ao avô que ela se dirige para compreender os rituais da sinagoga, o qual se consolida como a principal autoridade judaica em sua vida. Podemos, ainda, observar a magia provocada pela beleza e o mistério dos ensinamentos judaicos e da língua hebraica para Rose. Marques acrescenta que “o mistério dos ritos ancestrais é, também, um convite à evasão do espírito que vagueia pelas histórias do velho testamento" (p. 73).

Assim, esse encantamento da menina pelos textos sagrados explica-se pela sua parte de mistério, ou seja, pela incapacidade de apreensão total de seu sentido. Berta Waldman ressalta "a particularidade de ser o Deus judaico uma inscrição na linguagem, onde deve ser buscado, mas não apreendido, obrigando aquele que o busca a retornar sempre. A abertura para uma interpretação multiplicadora - eis a herança judaica por excelência" (WALDMAN, 2002, p. 27). A fascinação de Rose pelas palavras nos remete a essa busca incessante pelo sentido, pela chave do segredo do mundo guardada na língua, o que une personagem e autor, criatura e criador. Segundo Rose, essa mística da língua permite distinguir o hebraico, língua encantada, do alemão, língua desencantada:

Apesar de eu não saber ler, distinguia bem entre as letras hebraicas, impressas no lado esquerdo do devocionário, e as alemãs, no lado direito. As hebraicas agradavam-me mais: vistosas, arredondadas, levavam por cima e por baixo, pontinhos e tracinhos, dançavam por assim dizer, livremente no espaço, enquanto as alemãs, impressas a duas colunas, eram magrinhas, hirtas, bem comportadas. $\mathrm{O}$ lado das letras hebraicas fazia pensar numa cabeça endiabrada, cheia de caracóis; o outro, o das letras alemãs, na cabeça bem penteada de uma senhora idosa, com monótona risca ao meio. [...] Embrulhados no talete, de barretinho ou simples chapéu na cabeça, os homens murmuravam as orações. O meu avô era o mais bonito deles todos, com o seu corpo alto e barretinho de veludo preto sobre o cabelo branco. (LOSA, 1987, p. 40) 


\section{Arquivo Maaravi}

Aos olhos de Rose, a multiplicidade de sentidos associada à herança judaica parece encontrar sua forma perfeita na grafia hebraica. Interessante observar a associação entre o sagrado e o profano pelo uso que ela faz do adjetivo "endiabrado" para caracterizar a "cabeça cheia de caracóis". Para ela, a grafia hebraica não remete à imagem de um ser angelical, mas levado, travesso, transgressor, contrapondo-se à grafia alemã na sua contenção. É por meio da comparação das duas grafias que a menina faz uma primeira oposição entre a liberdade sentida no seio da comunidade afetiva judaica e a opressão sentida na sociedade alemã. E a imagem do avô embrulhado nos rolos do talit faz com que esse personagem esteja envolvido pela beleza, liberdade e mistério dessa língua que tanto cativa a sua neta.

Mas o avô não é tão somente a encarnação da tradição judaica ancestral, mas de um judaísmo aberto à alteridade humana. Podemos observar essa abertura pela relação de amizade estabelecida entre Markus e um prisioneiro russo:

[...] o avô Markus conversava frequentemente com um dos russos.

- Não é verdadeiramente russo?, perguntei.

- É verdadeiramente russo, sim. Tem cultura e aprendeu o alemão na escola. Embora cada terra tenha a sua língua própria, a gente pode, se tiver prazer nisso, aprender línguas estrangeiras para conversar com estrangeiros e ler os livros que eles escrevem.

Eu disse que queria aprender todas as línguas do Mundo [...]

Quando o perigoso "jogo de guerra" chegou ao fim, o russo que falava alemão despediu-se. Abraçou o avô como se fosse um amigo e não um inimigo e deixou ficar uma fotografia sua, que o avô colou no álbum da família. (LOSA, 1987, p. 31)

Vemos nesse trecho, por meio da palavra "jogo", a imagem pueril que a guerra revela mesmo aos olhos de uma criança, observadora da insensatez do mundo dos adultos. A desconstrução dos paradigmas amigo/inimigo, familiar/estranho, família/estrangeiro por Markus corrobora com essa ideia. O avô ensina que é por intermédio do aprendizado da língua do outro que podemos mais facilmente quebrar esse paradigma. Nesse sentido, Tzvetan Todorov explica que a expressão verbal opunha os gregos, nós, e os Bárbaros, os outros, os inimigos (TODOROV, 2008, p. 33). Ultrapassando as fronteiras diegéticas, Losa parece ter escutado os ensinamentos do avô Markus, aproximando-se da cultura portuguesa pela escrita 
na sua língua adotiva. A autora situa-se, assim, entre o ficcional e o referencial, entre o passado na Alemanha recriado no presente da escrita em língua portuguesa. Ela cria, portanto, uma "paratopia", segundo o conceito de Dominique Maingueneau, para quem “o escritor não tem lugar de estar" (...) ele alimenta a sua criação do caráter radicalmente problemático de sua própria pertença ao campo literário e à sociedade" (MAINGUENEAU, 2004, p. 85). ${ }^{6}$

A primeira grande prova da vida de Rose vem com a separação entre ela e o avô. A menina volta a viver na casa dos pais, onde sente a indiferença da mãe, fato que lhe marca fortemente:

Ninguém me contava histórias, à noite. A minha mãe sentava-se por uns momentos à borda da cama e obrigavame a uma reza breve [...].

- Talvez queiras confessar alguma coisa a Deus ou fazer-lhe um pedido. [...].

E pôs-me um peso na consciência. Devia eu esconder alguma coisa a Deus? (...) O avô Markus sabia dizer coisas maravilhosas: "Rose, és o melhor que tenho" ou "Que seria de mim, pecador, se não fosses tu?". O avô Markus sabia falar do amor, sabia amar e mostrar que amava. A minha mãe escondia os sentimentos; talvez soubesse amar, não sei, mas não sabia dizê-lo nem mostrá-lo (...). Não levou muito tempo a familiarizar-me com toda a gente. [...] Os habitantes da pequena cidade faziam parte de mim [...] e ainda hei-de falar neles, duns que eram amigos e ficaram sempre amigos, de outros que de amigos se fizeram inimigos e ainda de alguns que, desde sempre, não gostavam de judeus e me atormentavam com a sua hostilidade. (LOSA, 1987, p. 59, 61)

A dureza da mãe no contato com Rose associa-se à sua impossibilidade de abordar a religião de uma forma menos punitiva e mais afetiva. Podemos, portanto, constatar que, no romance em questão, a degradação dos laços familiares, acompanha-se de uma incapacidade de manter o espírito judaico vivo no seio da família. Se o provérbio diz que "Deus não podendo estar em toda a parte, criou as mães" (WIGODER, 1996, p. 659), ${ }^{7}$ essa mãe ausente não consegue transmitir a presença divina à sua filha. É o avô que assumiria o lugar da mãe nesse contexto.

Como podemos observar, nessa segunda sequência do romance, Rose, ainda criança, tem seus primeiros contatos com a violência antissemita. $\mathrm{O}$ universo 


\section{Arquivo Maaravi}

diegético é, portanto, construído com base no enfraquecimento do núcleo familiar e comunitário judaico, por um lado, e no fortalecimento do antissemitismo, por outro. Como se a vulnerabilidade de um campo facilitasse a invasão pelo campo adversário.

No trecho seguinte, a inimizade dos habitantes da cidade, ressentida pela criança, torna-se palpável na sua adolescência. Estudante no colégio, Rose é confrontada à hostilidade de uma colega de classe que, em meio a uma aula de história, tomaa por uma inimiga histórica:

Numa das aulas de História o professor estava a falar sobre a perseguição aos cristãos na Velha Roma e, em certa altura, dirigiu-se a mim para eu relatar o que sobre o assunto sabia. Além de estar mal preparada, aquele professor inibia-me e não conseguia concentrar-me rapidamente.

- Vamos, vamos, disse ele na sua voz monocórdica, espero que não estejas completamente em branco.

Nesse momento ouvi cochichar atrás de mim. Era Helene, filha dum famoso médico. O professor franziu a testa:

- Quem é que falou?

- Fui eu, respondeu Helene.

- Que é que disseste?

- Helene calou-se. E o professor irritado:

- Responde!

Mas Helene continuou calada [...] Isto não fica por aqui! Quero conversar contigo depois da aula, Helene.

Depois de ter falado com ele a sós, Helene chamou-me e segredou:

- Sabes?, eu tinha dito à Erika que tu, já se vê, não te podias interessar grandemente pela perseguição aos cristãos por seres judia. [...] Decerto julgava-se discreta. Mas eu pressentia-lhe a perfídia. (LOSA, 1987, p. 117-118)

Por trás da aparente ingenuidade do comentário de Helene, Rose vê erguer-se um muro, construído pelo discurso nazista, separando judeus e cristãos. $\mathrm{O}$ prenúncio da guerra já se anuncia na contaminação dos adolescentes pelo antissemitismo. Demonstração da necessidade de afirmação atávica moderna que vai buscar pseudo-argumentos nos tempos mais remotos. Ainda que neste trecho o professor de história não mostre claramente sua hostilidade para com os 


\section{Arquivo Maaravi}

judeus, os temas de sua aula são usados, pelos alunos, como combustível para alimentar o espírito de inimizade:

Outro acontecimento talvez insignificante e, no entanto, inesquecível para mim: numa dessas manhãs de Inverno [...] vínhamos do liceu [...]. À frente, no meio dos rapazes, Käte dava passos largos. Quando nos aproximamos da sinagoga, vi-a baixar-se, fazer uma bola de neve que atirou contra o templo e ouvi-a soltar gargalhadas. Os rapazes que a acompanhavam imitaram-na. [...] O corpo escaldava-me. Anni apressou-se a falar: o professor de História isto, o professor de História aquilo... Senti o propósito e isso ainda era pior. [...] Com o tempo comecei a pensar na minha incapacidade de me defender. [...] Mas lembro-me nitidamente de um outro receio que me apoquentava paralelamente: incomodava-me apanhar os outros numa indelicadeza, vê-los na necessidade de se justificaram, de se humilharem diante de mim. Entre ser-se humilhado ou ver os outros humilharem-se diante de nós, a primeira situação é mais deprimente mas a segunda é mais penosa. [...] A minha mãe tomava atitudes diferentes das minhas. (LOSA, 1987, p. 118-119)

Ao mesmo tempo em que observamos a fealdade dos supostos amigos de Rose, certificamo-nos do espírito humanista da autora encarnado em sua protagonista. A ausência de reação da menina face à agressão de seus amigos é, portanto, sentida menos como um sinal de covardia e mais como um gesto de compaixão pela imperfeição humana. Recusando-se a humilhar os seus colegas, Rose opõese ao espírito nazista, enfrentando de forma pacífica a opressão reinante em seu país. Nesse aspecto, mãe e filha divergem. A insensibilidade da mãe em relação à sua própria filha associa-se aqui à reação de impassibilidade face às agressões antissemitas. Contrariamente à figura do avô, transbordante em atenção aos seus e aos outros, à mãe é associada ao sentimento de carência e de omissão. A neta identifica-se, portanto, com o avô, tentando, através de sua imagem, preencher o sentimento de exclusão que a persegue tanto na sociedade quanto no seio de sua própria família.

No conto "Gringuinho", de forma semelhante ao romance de Ilse Losa, a figura da mãe é marcada pela imagem da indiferença, em contraposição ao carinho recebido pelo avô no shtetl. No caso de "Gringuinho", o protagonista não se encontra em terra natal, mas já em terra de exílio. Num quadro geo-histórico que podemos situar como sendo a periferia de uma grande cidade brasileira, durante a era Vargas, o menino é vítima da xenofobia dos nativos. Assim como acontece 


\section{Arquivo Maaravi}

Revista Digital de Estudos Judaicos da UFMG

ISSN: $1982-3053$

com Rose, Gringuinho é agredido pelos colegas da escola e pelas crianças na rua. Mas, ao contrário do romance de Losa, vemos em "Gringuinho" a ação direta da professora como agente agressor. Berta Waldman, em sua análise da obra Contos do imigrante, associa o uso do termo "indesejável" à imagem do estrangeiro, como "marca xenófoba que enquadra linguisticamente o estrangeiro como nocivo e inadequado ao modelo proposto pelo projeto estadonovista" (WALDMAN, 2002, p. 71). O conto situa-se, assim, num contexto de euforia nacionalista e de um projeto étnico-político em que o judeu é associado à ameaça comunista. Nesse sentido, Maria Luiza Tucci Carneiro afirma que "a trajetória política de Vargas seria delineada pela persistência do seu pensamento antissemita" (CARNEIRO, 2005, p. 346).

Gringuinho é a encarnação do "indesejado" do qual fala Waldman. Vítima constante de agressões, ele percebe o seu país de exílio como um lugar de desterro. $\mathrm{O}$ sentimento de exclusão que esse personagem carrega é representado pela destituição do seu nome, substituído pelo apelido injurioso que lhe é atribuído pelos nativos. Em vão, Gringuinho procura refúgio contra essa violência social no ambiente doméstico. É por essa cena que o conto tem início: “Chorava. Não propriamente o medo da surra em perspectiva, apesar de roto o uniforme. Nem para isso teria tempo a mãe. [...] Que trocasse a roupa e fossa buscar cebolas no armazém. Nada Mais." (RAWET, 2004, p. 42).

Contrariamente ao texto de Losa, é a imagem dolorosa da mãe que inaugura a narrativa, indicando a preponderância do presente de sofrimento sobre a memória de uma infância feliz com o avô no shtetl. No trecho, escutamos tanto a voz do narrador, quanto a voz do menino em discurso indireto livre. Assim, contrariamente ao texto de Losa, não é um narrador autodiegético que toma posse de seu discurso para contar suas memórias, mas um narrador heterodiegético que se deixa invadir pelas vozes dos personagens. Num verdadeiro tormento polifônico, através da voz do protagonista, infiltrada no discurso do narrador, escutamos tanto a própria reflexão de Gringuinho quanto a transposição da frase da mãe dentro do seu pensamento: "Que trocasse a roupa e fossa buscar cebolas no armazém. Nada Mais.". Essa estratégia narrativa ressalta a dificuldade de se apropriar da palavra para liberar a memória individual, marcada por uma situação traumática. $\mathrm{O}$ narrador fica, assim, num espaço intersticial entre o distanciamento e o envolvimento afetivo, entre o individual e o coletivo, entre o referencial e o ficcional. Assim, a diegese é invadida, de forma obsessiva e angustiante, pela voz da mãe no seu pedido de cebolas, contrastando com o apelo surdo do filho pelo carinho da mãe.

A indiferença da mãe para com a dor de Gringuinho é notável e beira à crueldade, pois ela pede à criança para comprar um legume com efeito lacrimogêneo, quando seus olhos já transbordam em lágrimas. Podemos, portanto, notar aqui 
que a família, tal como no romance de Losa, mas de forma ainda mais pungente, torna-se um agente de sofrimento para a criança. Em "Gringuinho", contrariamente ao fenômeno de reagrupamento comunitário que se observa comumente num contexto de imigração, a mãe não consegue partilhar com ele a afetividade ligada à herança judaica. Também é incapaz de compreender a dor causada pela discriminação da qual ele é vítima na sociedade brasileira. Essa mulher está completamente absorvida pelo duro cotidiano em que vive, preenchida pelas atividades domésticas e pela presença de um bebê:

Tirou da gaveta a fralda seca, e entre o ninar e o gesto de troca passou-lhe a descompostura. [...] Ele tentou surpreender-lhe o olhar, conquistar a inocência a que tinha direito. Depois gostaria de cair-lhe ao colo, beijá-la e contar tudo, na certeza de que lhe daria a razão. Mas nada disso. [...] Traria as cebolas. E não contaria que ao ser repreendido na escola, na impotência de dar razões, quando a velha principiou a amassar-lhe a palma da mão com a régua negra e elástica, não se conteve e esmurrou-lhe o peito rasgando o vestido. Quando atravessou o portão acelerou a marcha impelido pelo desejo de ser homem já. Julgava que correndo apressaria o tempo. Seus pés saltitavam no cimento molhado, como outrora deslizavam, com as bonitas ferradas, pelo rio gelado no inverno. (RAWET, 2004, p. 44-45)

Mãe e filho não conseguem dialogar, mesmo a comunicação não-verbal, que poderia se realizar por gestos de carinho, não tem espaço no conto. Recusandose a tratar Gringuinho como uma criança, a mãe provoca seu amadurecimento precoce e seu recrudescimento ("desejo de ser homem já"). A imagem do menino correndo parece provocar um aceleramento simultâneo da intriga rumo a um suposto desfecho do conto. No entanto, o encerramento da narrativa e do sofrimento do protagonista não passam de uma ilusão. O texto fica atrofiado pelo retorno constante da dor: da separação do avô ("rio gelado") ao presente de exclusão ("cimento molhado"). Não há, portanto, nem desenvolvimento textual gradual, nem amadurecimento natural do protagonista. Nessa cena, a revelação da agressão cometida contra a professora marca o aborto da infância de Gringuinho por conta da sua exclusão social e familiar. Da mesma forma, a narrativa, que poderia se prolongar em longas peripécias acompanhando o percurso do personagem até a idade adulta, encontra um fim ao mesmo tempo abrupto e inacabado. Tal como o choro, o murro na professora marca a erupção do corpo na ânsia vã de comunicação, como podemos observar no trecho seguinte, narrado em flashback: 


\section{Arquivo Maaravi}

Abrira o livro na página indicada, tenteando, como cego, para entrar no compasso da leitura. Nem às figuras se acostumara, nem às histórias estranhas para ele, que lia aos saltos. Fala Gringuinho. Viera de trás a voz grossa, de alguém mais velho. Fala gringuinho. Insistia. Ao girar o pescoço na descoberta da fonte fora surpreendido pela ordem da leitura. Olhou os dentes aguçados insinuando-se no lábio inferior como para escapar. Explicar-lhe? Como? Mudo curvou a cabeça como gato envergonhado por diabrura. Era-lhe fácil a lágrima. (RAWET, 2004, p. 44)

Podemos aqui observar a carga de violência contida no apelido "Gringuinho". O emprego do diminutivo, que poderia ser um sinal de carinho, revela-se, pela associação com o adjetivo "burro", uma marca de inferioridade. A relação desigual dominante/dominado é, assim, estabelecida por meio de alguns pares dicotômicos: professor/aluno, adulto/criança, palavra/silêncio, nativo/estrangeiro, sendo a tensão contida nessa última relação reforçada pelo termo injurioso atribuído ao personagem. Além disso, a destituição do seu nome próprio, substituído por um apelido depreciativo, reforça o déficit de identidade desse personagem, sua dupla orfandade: afastado de sua terra materna e abandonado pela sua terra de adoção.

O assédio moral do qual ele é vítima é perpetrado tanto pelas crianças como pela professora, suposto modelo de conduta a seguir. Ainda mais grave é a violência que esse adulto adquire, por sua força de palavra enquanto autoridade na sala de aula. Em contraposição, temos a fragilidade de expressão da criança, fato agravado por sua condição de estrangeiro. A escola enquanto microcosmo da sociedade brasileira utiliza uma "pedagogia nacionalista", conceito de Homi Bhabha, que reenvia a um discurso de formação cultural baseado em "uma linguagem de pertença nacional sobrecarregada de apólogos atávicos" (BHABHA, 2007, p. 228). ${ }^{8}$ Ora o estrangeiro, enquanto recém-chegado, não é formado pela mesma narração social. É por isso que ele lê os textos saltando palavras: não somente a língua portuguesa lhe é estranha, mas as histórias dessa nova nação lhe são igualmente. Assim, Gringuinho representa a nação moderna clivada entre o pedagógico e o performativo, o que Bhabha explica como “alienada de sua própria autogeração [...] espaço limiar significativo marcado num modo interno pelos discursos de minorias, as histórias heterogêneas de povos tomadas entre si" (BHABHA, 2007, p. 235). ${ }^{9}$

Nesse sentido, a ordem Fala gringrinho é a expressão da violência do grupo hegemônico - da qual a professora da escola é a encarnação mais perversa contra a alteridade do estrangeiro. No trecho a seguir podemos ver como a "pedagogia nacionalista" está infiltrada já no discurso das crianças, 
disseminando uma xenofobia cordial, à brasileira. Essa imagem remete-nos à aula de história de $O$ mundo em que vivi, em que os adolescentes apoderavam-se do discurso nazista. A hostilidade sentida por Gringuinho, na segunda parte de sua infância vivida numa cidade brasileira, contrasta com os seus idílicos primeiros anos no shtetl. Assim como no texto de Losa, a figura do avô é a marca desse primeiro período da vida do protagonista:

Ontem rolara na vala com Caetano após a discussão. Atrapalhou o jogo. O negrinho crescera em sua frente no ímpeto de derrubá-lo.

- Gringuinho burro!

Ajeitou sobre a cama o uniforme. A lição não a faria. Voltar à mesma escola, sabia impossível também. [...] Antigamente, antes do navio, tinha seu grupo. Verão, encontravam-se na praça e atravessando o campo alcançavam o riacho, onde nus podiam mergulhar sem medo. [...] A voz da mãe repetia o pedido de cebolas. Coçar de cabeça sem vontade. No inverno havia o trenó que carregava para montante, o rio gelado onde a botina ferrada deslizava qual patim. Em casa a sopa quente de beterrabas, ou o fumegar de repolhos. Sentava-se no colo do avô recémchegado das orações e repetia com entusiasmo o que aprendera. Onde o avô? Gostava do roçar da barba na nuca que lhe fazia cócegas, e dos contos que lhe contava ao dormir. Sempre milagres de homens santos. Sonhava satisfeito com a eternidade. A voz do avô era rouca, mas era boa de ouvir. Mais quando cantava. Os olhos no teto de tábuas, ou acompanhando a chaminé do fogão, a melodia atravessava-lhe o sono. Hoje entrara tarde na sala. Não gostava de chamar a atenção sobre si, mas teve que ir à mesa explicar o atraso. Cinqüenta pares de olhos fixos em seus pés que tremiam. O pedido de cebolas veio mais forte. Gargalhada maciça em contraponto aos titubeios da boca, olhos e mão. A custo conteve as lágrimas quando tomou o lugar. Chorava assim quando no primeiro sábado saiu de boné com o pai em direção da sinagoga. Caetano, Raul, Zé, Paulo, Betinho fizeram coro repetindo em estribilho o gringuinho. (RAWET, 2004, p. 42)

Oriundo de um meio onde a infância é carregada de candura, Gringuinho mostra-se como uma presa fácil diante da agressão das outras crianças. As 


\section{Arquivo Maaravi}

Revista Digital de Estudos Judaicos da UFMG

ISSN: $1982-3053$

tensões sociais entre brasileiros e estrangeiros são aqui metaforizadas por uma partida de futebol, onde o estrangeiro é visto como o "indesejado", aquele que "atrapalha o jogo". O menino Caetano representa a imagem estereotipada do "verdadeiro" homem brasileiro: negro, bom de bola e imbuído de um senso de malandragem que se opõe à ingenuidade de Gringuinho.

A imagem do navio se apresenta como o símbolo mnemônico da passagem entre as duas margens da existência do protagonista. Ele nunca consegue, entretanto, completar a travessia, está sempre num entre dois: entre as beterrabas e os repolhos do shtetl e as dolorosas cebolas que sua mãe lhe pede para comprar no supermercado. No fim desse trecho, podemos observar que a voz autoritária da mãe se confunde com o riso zombeteiro de seus colegas de classe. Também o judaísmo imposto pelo pai, sinalizado pelo uso do kippa, é visto como uma agressão, sinal distintivo de uma identidade que se opõe ao ideal brasileiro de amálgama cultural. A condição de exclusão do protagonista é reforçada pela enumeração dos nomes próprios de todos os meninos brasileiros, opondo-se ao seu apelido depreciativo. É na memória do avô que Gringuinho busca proteção contra a incompreensão mútua da família e da sociedade. Assim como no romance de Losa, é à imagem do "colo", como esteio pessoal, que o avô se associa ("Sentava-se no colo do avô"). É também de forma sensorial que, pela voz do avô, o judaísmo lhe toca a alma. A imagem do ancião bíblico é, em Rawet igualmente, associada ao avô enquanto autoridade não-coercitiva, transmitindo a experiência da presença divina através da palavra. Por meio da figura do avô, apresentada nas narrativas de Losa e Rawet, temos uma valorização da transmissão oral dos textos sagrados, ligados tanto ao poder da palavra como ao da escuta, e, por consequência, à aproximação da comunidade em torno desse círculo. Vemos, portanto, que os textos dos dois escritores propõem uma visão do judaísmo mais afetiva e menos dogmática, de forma a reforçar a força comunitária através do espírito de partilha.

Os textos desses dois autores, por conta de sua temática, remetem-nos ao Bildungsroman, também conhecido como "romance de formação" ou "romance de aprendizagem", gênero literário surgido na Europa do século 18. Segundo Florence Bancaud-Maënen, o "romance de formação" tem por objetivo "representar a educação e o desenvolvimento individual de um herói, de sua juventude até a sua maturidade, e de fornecer, por meio de uma intriga combinando revelação gradual da verdade e iniciação progressiva do herói e do leitor, a visão otimista do progresso contínuo do sujeito". (BANCAUDMAËNEN, 2005, p. 8). ${ }^{10}$

Se o objetivo essencial atribuído ao romance de formação é respeitado pelos dois autores, alguns pontos de divergência, no caso de Rawet, fazem-nos preferir o emprego do termo "narrativas de formação" para uma análise comparada. 


\section{Arquivo Maaravi}

Revista Digital de Estudos Judaicos da UFMG

ISSN: $1982-3053$

Primeiramente, se a existência da figura do herói se confirma no texto de Losa, encarnada pela resistência e pelo otimismo de Rose, o mesmo não pode ser dito com relação ao texto rawetiano. Gringuinho, ao agredir a professora, torna-se mesmo um anti-herói. Ainda, o texto de Rawet apresenta uma condensação extrema da intriga, indicando o amadurecimento abrupto do protagonista. Isso impossibilita a revelação gradual dos fatos, o que acompanharia o crescimento natural do personagem. Assim, o conto, enquanto forma textual breve, é a formato narrativo ideal para representar a vida abreviada do protagonista.

Além disso, a fim de exprimir o desregramento da vida de Gringuinho, o escritor brasileiro quebra a estrutura narrativa convencionalmente atribuída ao "romance de formação", desrespeitando a ordem cronológica das etapas do crescimento humano. Por fim, Rawet construiu uma narrativa onde não há preponderância de uma pessoa verbal e de uma voz narrativa, mas um espaço polifônico marcado pelo emprego do discurso indireto livre. Impossível para o narrador de se distanciar do seu personagem. Doloroso também lhe deixar assumir o discurso. Difícil ainda fazer uma retrospectiva da vida de Gringuinho sem a presença traumática da voz materna e da voz da professora, representadas pelos leitmotivs "Que fosse buscar cebolas no armazém" e "Fala Gringuinho". Não há estabilidade nem na narrativa, nem no personagem, mas a erupção de vozes e corpos. Não há progresso contínuo do sujeito, mas desorientação. O aprendizado social realizado tanto pelo protagonista como pelo leitor é conseguido graças à incorporação da violência que a própria sociedade transmite, para que seja usada como força de rebelião contra o mal por ela provocado. Trata-se, portanto, de um aprendizado a contrario, por afastamento com relação ao modelo social. Nesse sentido, tanto o texto de Losa quanto de Rawet cumprem a finalidade pedagógica de um "romance de formação" que "se encerra no momento em que, tornado adulto e alcançando o conhecimento de si mesmo e de seu lugar no mundo, ele [o herói] pode viver como adulto numa sociedade de adultos" (BANCAUDMAËNEN, 2005, p. 35). ${ }^{11}$ Pela ternura do discurso de Rose, alimentado pela memória do avô, esta se reconcilia com os seus agressores, reatando igualmente os seus laços com a comunidade judaica. Gringuinho, no entanto, exprime uma lesão afetiva incurável com a perda do avô e a indiferença da mãe. Esse vazio é preenchido por um sentimento de raiva que o faz crescer precocemente e se distanciar tanto da comunidade judaica, quanto da sociedade de acolhida. Se o antissemitismo faz Rose aproximar-se de suas origens como meio de resistência, Gringuinho resiste à xenofobia pelo isolamento radical.

Por intermédio desses dois magníficos "textos de formação", Losa e Rawet apresentam-nos, portanto, a importância da figura do avô judeu como transmissor de um judaísmo afetivo, esteio de uma comunidade judaica enfraquecida pela violência do antissemitismo - em terra natal - e pela xenofobia 
- em terra de acolhida. Entre a utopia da Boneca-Mais-Linda-do-Mundo e a distopia do vestido rasgado da professora o que prevalece é, sobretudo, o apelo ao afeto.

* Karina Marques é Professora de língua portuguesa, literatura e civilização brasileira na Universidade de Rennes, França. Doutora em literatura brasileira e portuguesa comparada pela Universidade Sorbonne Nouvelle - Paris 3, é ainda membro do Centro de Estudos sobre os Países Lusófonos (CREPAL), nessa mesna universidade.

\section{Notas}

${ }^{1}$ Esta e as demais notas são traduções nossas: "[...] de libérer rétrospectivement certaines possibilités du passé historique".

2 " [...] faisant place à l'autre".

3 "[...] tout à la fois de multiples appartenances et le sol commun de l'appartenance humaine".

4 "Dans la société biblique, personnes qui acquéraient un statut spécial d'autorité en raison de leur âge, de leur sagesse".

5 “[...] chargés de faire l'expérience de la divine Présence, de recevoir l'inspiration et de partager la responsabilité du commandement avec Moïse". 6 “[...] l'écrivain n'a pas lieu d'être [...] il nourrit sa création du caractère radicalement problématique de sa propre appartenance au champ littéraire et à la société".

7 "Dieu ne pouvant pas être partout, il a créé les mères".

8 “[...] un langage d'appartenance nationale surchargé d'apologues ataviques".

9 “[...] alienée de sa propre autogénération [...] espace liminal significatif marqué sur un mode interne par les discours de minorités, les histoires hétérogènes de peuples prises entre eux".

10 "[...] représenter l'éducation et de développement individuel d'un héros, de sa jeunesse à sa maturité, et le livrer par une intrigue combinant dévoilement graduel de la vérité et initiation progressive du héros et du lecteur, la vision optimiste d'un progrès continu du sujet".

11 " [...] s' achève au moment où, devenu adulte et parvenu à la connaissance de lui-même et de sa place au monde, il peut vivre en adulte dans une société d'adultes". 


\section{Referências}

BANCAUD-MAËNEN, Florence. Le roman de formation au XVIIIe siècle en Europe. Paris: Armand Colin, 2005.

BHABHA, Homi. Les lieux de la culture. Une théorie postcoloniale. Paris: Éditions Payot e Rivages, 2007.

BRASIL, Assis. Samuel Rawet, um marco literário. Jornal de Letras. Rio de Janeiro: junho de 1974.

CHIANTARETTO, Jean-François. L'Écriture de soi peut-elle dire l'histoire? Paris: Centre Pompidou, 2002.

KLIDZIO, Natalia. Um olhar sobre a cidade do escritor Samuel Rawet: Klimontóv". In: KIRSCHBAUM, Saul (Org.). Dez ensaios sobre Samuel Rawet. Brasília: LGE editora, 2007.

LOSA, Ilse. O mundo em que vivi. Porto: Edições Afrontamento, 1987.

LOSA, Ilse. À flor do tempo. Porto. Edições Afrontamento, 1997.

PALLA, Maria Antonia. Ilse Losa. Perdemos o sentido da festa. O século ilustrado. Lisboa, 1973.

RAWET, Samuel. Samuel Rawet: contos e novelas reunidos. André Seffrin (Org.). Rio de Janeiro: Civilização Brasileira, 2004.

RICEUR, Paul. Temps et récit 3: Le temps raconté. Paris: Éditions du Seuil, 1985.

TODOROV, Tzvetan. La peur des barbares. Paris: Éditions Robert Laffont, 2008.

TUCCI CARNEIRO, Maria Luiza. Imigrantes e refugiados judeus em tempos sombrios: Brasil, 1933-1948. In: - Keila Grinberg (Org.). Inquisição, imigração e identidade: os Judeus no Brasil. Rio de Janeiro: Civilização Brasileira, 2005.

WALDMAN, Berta. Entre passos e rastros. São Paulo: Editora Perspectiva, 2002.

WIGODER, Geoffrey Wigoder. Dictionnaire Encyclopédique du Judaïsme. Paris: Cerf/ Robert Laffont, 1996.

MAINGUENEAU, Dominique. Le discours littéraire. Paratopie et scène d'énonciation. Paris: Armand Colin, 2004. 